DOI 10.25712/ASTU.2518-7767.2015.01.010

\title{
«ПЕСНЬ ПЕСНЕЙ»
}

Чертогова Марина Юрьевна

ИскусствовеА, заместитель директора

по научной работе Кемеровского музея

изобразительных искусств,

член Союза художников России, член

Ассоциации искусствоведов России

(АИС).

Россия, г. Кемерово.

chertog_marina@mail.ru

\section{Аннотация}

Статья преАставляет историю возникновения и обзор выставочного проекта «Песнь Песней» в Кемеровском областном музее изобразительных искусств. На выставке были представлены работы женщин-художников Сибирского федерального округа. Проводятся парацлели с выставкой «Искусство женского рода», состоявшейся в 2002 году в Государственной Третьяковской галерее.

КАючевые слова: выставка, Песнь Песней, женщины-художницы, Сибирь, Кемерово.

\section{Библиографическое описание дмя цитирования:}

Чертогова М.Ю. «Песнь Песней» // Искусство Евразии. - 2015. - № 1 (1). - С. 123 134. DOI: 10.25712/ASTU.2518-7767.2015.01.010. [Э^ектронный ресурс] URL: https://readymag.com/u50070366/416035/24/

Принято считать, что различать искусство по половому признаку - неоправданно, бессмысленно, Ааже оскорбительно: есть Художник, а кто он, мужчина или женщина, не имеет значения. С Аругой стороны, АюАской род изначально делится на Аве половины, полярные по своей природе, и это как фундаментальная Аанность земного мироустройства пронизывает все сферы человеческой жизни: социальную, политическую, интеллектуальную, культурную... Так есть, несмотря на всевозможные отклонения, Аопущения, искАючения. А если так, то это - как особый аспект отражения Аичности - имеет полное право быть темой специального изучения 5 .

\footnotetext{
${ }^{5}$ Художница Анна Броше, участница конференции «Женское искусство как проект будущего» (Москва, 2009): «Можно говорить о том, что нет различия в мужском и женском искусстве, но конкретно между мужчиной и женщиной есть колоссальная разница. Это существа, живущие абсолютно разным гормональным фоном. Они не могут функционировать одинаково, и соответственно, они не могут производить одни и те же вещи. Можно сказать, что человек должен выйти и встать над фризиологической ступенью - и тогда... что на это вы можете возразить?» [2].
} 


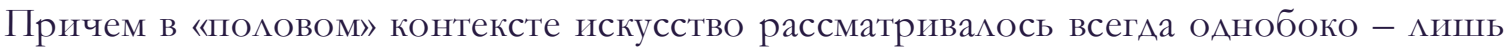
с точки зрения женского творчества, считавшегося явцением маргинальным, тогда как о мужском, существовавшем как само собой разумеющееся, вопроса никогда не стояло. Неравенство полов, утвердившееся в обществе с Аавних времен, и до сих пор окончательно не изжито.

История знает немало женщин, оставивших в искусстве значительный слеА и прочно вошедших в анналы изобразительной культуры, однако по сравнению с колцегами сильного пола их число несопоставимо ничтожно. На протяжении многих веков они появАялись в искусстве эпизодически, вопреки сложившимся нормам, сводившим роль женщины к материнству и домашнему очагу, - нормам, менявшимся с косной медлительностью, от столетия к столетию. Апофеозом женского равноправия в искусстве, как известно, стали русские художницы начала XX века - «амазонки авангарда» (Александра Экстер, Наталья Гончарова, Аюбовь Попова, Ольга Розанова, Варвара Степанова, Надежда УАальцова), которые наравне с художниками-мужчинами приняли активное участие в свершении художественной революции (опередившей социальную) - в формировании абсолютно новой эстетики, полностью опрокинувшей былые традиции.

Воссоздать панораму женского творчества в отечественном искусстве на протяжении пяти веков $(\mathrm{XV}-\mathrm{XX})$ - стало задачей масштабной выставки «Искусство женского рода», состоявшейся в 2002 году в Государственной Третьяковской галерее. Экспозиция вкАючала более Авухсот произведений разнообразных стилей и жанров: от средневекового шитья до актуальных объектов сегодняшних Аней. По сути, она показала историю русского искусства - без художников мужского пола и тем самым вызва^а широкий резонанс, бурные и ожесточенные споры. В обсуждении этой выставки профессиональное сообщество раскололось надвое - по половому признаку. Пресса писала, что мужчины-арт-критики высказались решительно против ее концепции или не усмотрели в ней вовсе никакой концепции; их колмеги-женщины выставку Аружно одобрили ${ }^{6}$.

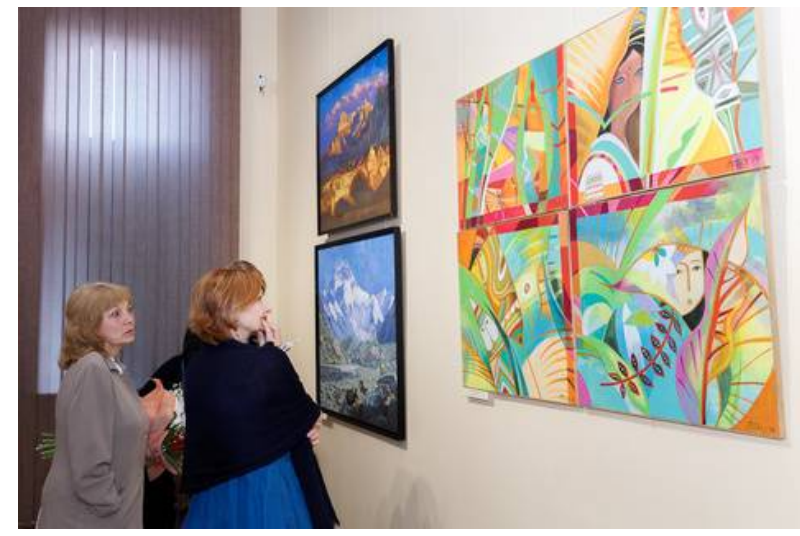

Ри. 1. Экспозичия выставки «Песнь песней».

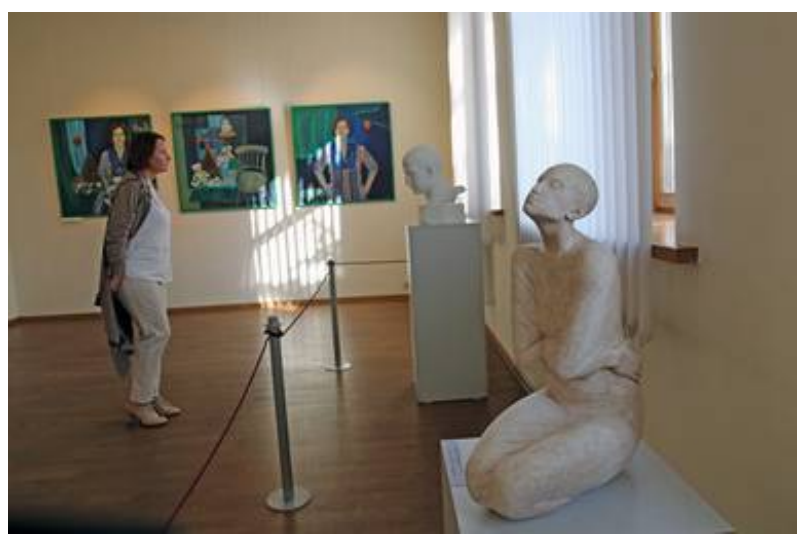

Рис. 2. Экспозичия выставки «Песнь песней».

\footnotetext{
6 Художница Елена Елагина: «Выставка показала, что женское искусство абсолютно не отличается от мужского. Для того чтобы сравнить уровни профессионализма, нужно сделать выставку «Искусство мужского рода», и тогда можно будет сделать объективные выводы. Такие выставки, как «Искусство женского рода» сразу становятся мишенью для критики, которая охотно вновь и вновь возвращается к проблеме «природного» предназначения женщины» [1].
} 
Стало быть, и в третьем тысячелетии, когАа практически во всех областях общественной жизни слабый пол выступает на равных с сильным, вопрос о женском искусстве по-прежнему остается волнующим и открытым.

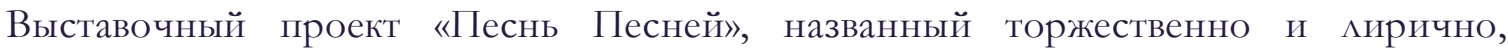
представцяет творчество современных художниц Сибири - самобытного края со своими истоками, историей, бытием.

Впервые на одной выставочной площадке собралась женская половина профессионацьного сообщества, и это, с одной стороны, нагляАно предъявило наличие оной, с Аругой - широко продемонстрировацо ее творческое Аицо. САовом, выявило женскую состав яящую современного искусства Сибирского федерального округа.

Актуальность Аанной выставки, полагаю, неоспорима. Во-первых, уже потому, что в истории профессионацьного искусства Сибири, начавшейся, по существу, в 1920-е годы, еще не было ни одной выставки (!), которая бы объединила и представила творчество региональных художниц, не считая мокальных выставок - групповых, городских, областных, проходящих время от времени, чаще по случаю Международного женского Аня 8 Марта. Во-вторых, именно сегодня численность и творческая активность сибирских художниц возросли так и настолько, что представить без них искусство Сибири уже немыслимо, и это - как тенденцию современного этапа развития - следует выявить, обозначить, продемонстрировать.

История профессионацьного искусства Сибири показывает, что число художниц на протяжении XX века росло хоть и неуклонно, но очень медленно. На этапе становления (1920-е) их было по самым смелым подсчетам чуть больше десятка (на всю необъятную территорию, от Омска до Иркутска), тогАа как художников-мужчин насчитывалось более ста ${ }^{7}$. В годы Великой Отечественной войны в Сибири появицись художницы, эвакуированные из европейской части Советского Союза; в 1950-80-е выпускницы художественных вузов страны, прибывшие сюда по целевым распределениям, согласно действовавшей государственной программе по превращению Сибири в край высокой культуры. Однако, будучи приезжими, большинство из них потом покидало суровый край, и численность женских рядов в региональных Союзах художников оставацась по-прежнему невысокой.

Ситуация начала выравниваться мишь к концу XX века, когда на территории Сибирского фелерального округа окончательно сложилась и окрепла система художественного образования ${ }^{8}$, когда стремитемьно нарастала тенденция к тотальному Аоминированию в студенческих массах представительниц женского пола. Все это не только увеличицо число молодых художниц, пополнявших творческие ряды почти ежегодно, с каждым выпуском, не только повысицо их рейтинг и профессиональную состоятельность - это изменило их родословную. Как говорится, где родились, там и пригодились: коренные сибирячки, не стенающие «В Москву! В Москву!», они

\footnotetext{
7 «Краткие сведения о художниках и деятелях искусства, живших в Сибири в 1920-х годах»в книге П. Д. Муратова [3].

8 Во второй половине XX века значительно возросло число средних специальных учебных заведений, в начале 2000-х - число специальных факультетов в высших учебных заведениях; в 1987 году был открыт Красноярский государственный художественный институт и творческие мастерские Регионального отделения «Урал, Сибирь и Дальний Восток» Российской академии художеств.
} 
искренне почитают родную земАю, ощущают с ней глубокую Аичную сопричастность и с благодарностью воздают ей должное: воспевают, исследуют, осмысляют.

Сегодня в сибирских отделениях ВТОО «Союз художников России» числится более трехсот художниц. Это в тридцать раз больше (!), чем их было в 1920-е годы, на этапе становления профессионального искусства Сибири, но все же меньше, чем колмег сицьного пола, примерно вдвое 9 . Статистика показывает, что по окончании вузов многие выпускницы все-таки предпочитают чистому творчеству традиционные ценности (семья, материнство, комфорт) и поэтому, не желая жертвовать женским счастьем, выбирают более востребованные профессии (например, рекламный или интерьерный дизайн), позволяющие обеспечить стабильный заработок, безбедную жизнь, иногда совмещая полезное с приятным. Так поступают многие, но не все.

Представляя колмектив сибирских художниц, выставочный проект «Песнь Песней» выявляет прежде всего именно тех, кто отАается искусству сполна и обладает незаурядным творческим «я», у кого свой собственный путь развития и сложившийся авторский стиль, чья роль в колцективе по-настоящему значительна и весома. Это не только художницы первого ряда, Аавно состоявшиеся в профессии, без которых панорама современного искусства Сибири будет выглядеть заметно неполной, недостаточно яркой, но и начинающие, при этом уже заявившие о себе - активно, убедительно, многообещающе (например, Анастасия Свинарева, Мария Точко).

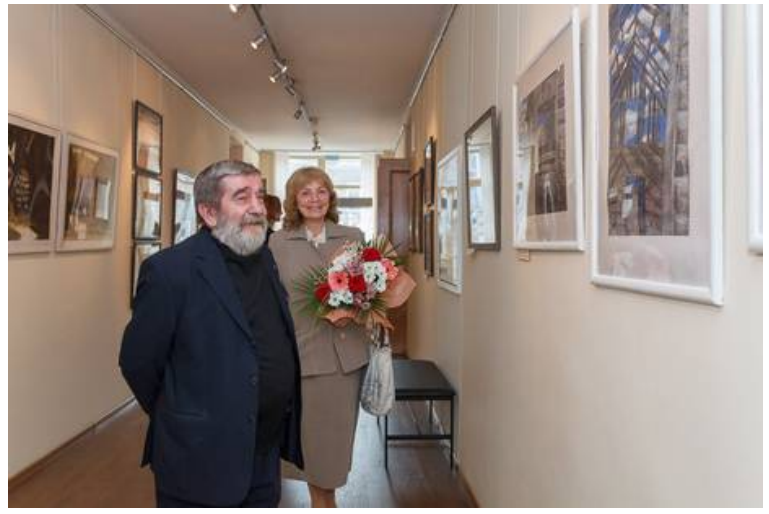

Рис. 3. Экспозичия выставки «Песнь песней».
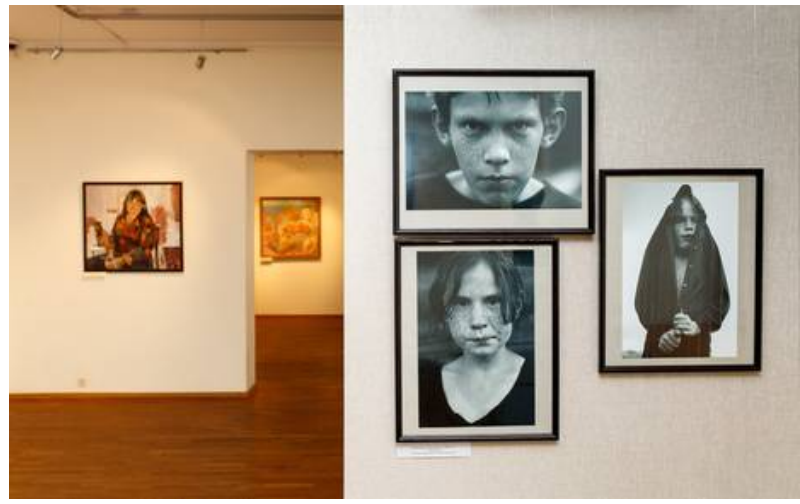

Рис. 4. Экспозичия выставки «Песнь песней».

Определиться в выборе таковых помог и глубокий анализ выставок послеАних десятилетий - больших и малых, виденных чаще воочию или внимательно изученных по каталогам-альбомам; и Аичное знакомство с большинством из художниц, у которых не раз была в мастерских, формируя колмекцию Аля музея, и с которыми сама не раз

\footnotetext{
${ }^{9}$ На сегодняшний день количественное соотношение между художниками сильного и слабого пола в составах сибирских коллективов ВТОО «Союз художников России» (тех, чьи члены участвуют в выставке) выглядит примерно так: 123 и 24 (Алтайское краевое отделение); 69 и 90 (Ииркутское областное отделение); 58 и 16 (Кемеровское областное отделение);112 и 80 (Красноярская региональная организация); 36 и 23 (Новокузнецкое городское отделение); 64 и 22 (Новосибирское областное отделение); 90 и 48 (Омское областное отделение); 38 и 34 (Томское областное отделение). Приведенные данные получены летом 2015 г. по запросу из региональных отделений ВТОО «Союз художников России».
} 
проводила выставки ${ }^{10}$. Помоглии комлеги-искусствоведы (В.Ф. Чирков, Т.Н. Микуцкая, О.Н. Шабалина, Н.В. Тригалева и Ар.) - из разных городов, авторитетные и многоопытные, к которым - из опасения ненароком «прошляпить» талант обращалась за дельным советом, всецело доверяя их мнению, вкусу.

Участницами выставки «Песнь Песней» стаАи около восьмидесяти художниц из региональных центров Сибирского федерального округа: Омска, Новосибирска, Томска, Кемерова, Новокузнецка (Кемеровской области), Барнаула, Красноярска, Иркутска, Усть-Илимска (Иркутской области). Подавляющее большинство являются членами ВТОО «Союз художников России» (63), причем немало молодых, вступивших в профессиональные ряды Аишь за последние пять мет (25), а Аевять из них - в 2015-м, едва оставив позади молодежные секции, форумы.

Примечательно, что самой старшей из участниц в этом гоАу исполнилось восемьдесят (Розалии Пантелеевой), самой младшей - всего двадцать три (Марии Точко). Это значит, что на выставке представлено искусство художниц всех ныне Аействующих поколений, начиная с того, которое выступило в Аалекие 1970-е годы. Время показало, что творческим Аолголетием обладают такие «семидесятницы», как T.М. Бельчикова (Томск), Р.В. Пантелеева (Томск), А.Н. Пастушкова (Барнаул), О.Н. Чукина (Кемерово).

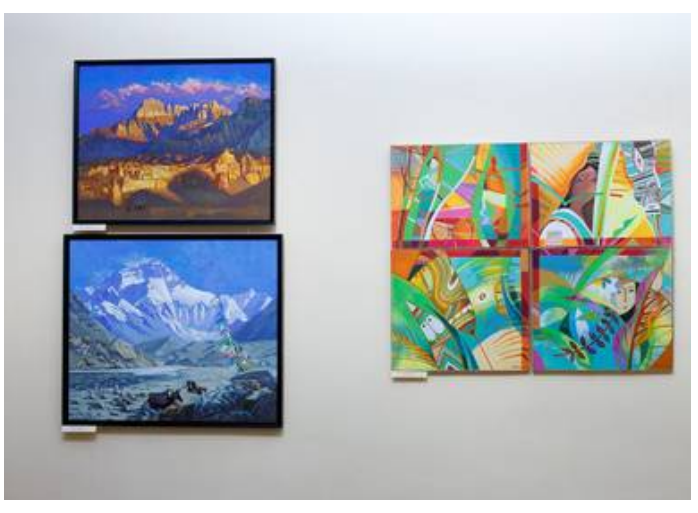

Рис. 5. Экспозичия выставки «Песнь песней».

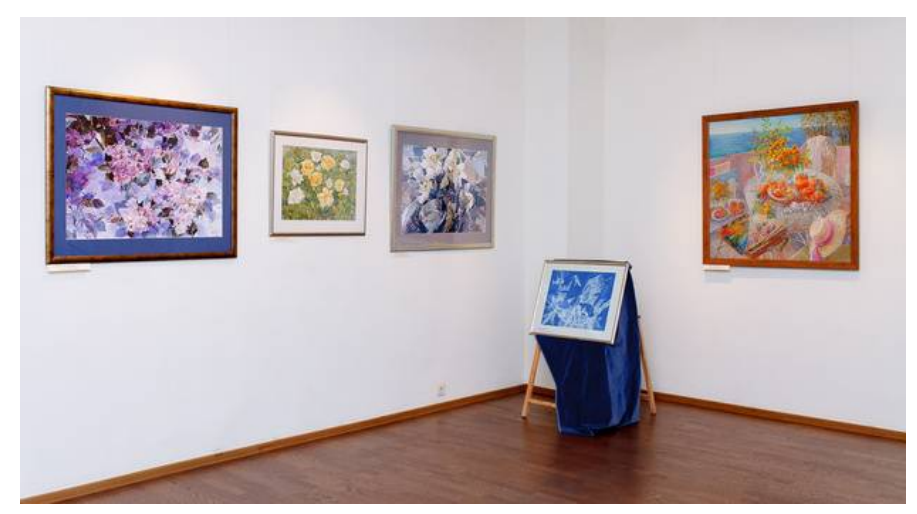

Рис. 6. Экспозичия выставки «Песнь песней».

Произведения, представленные на выставке, отбирались в Ава этапа: сначала авторы преАлагали их многочисленный ряд - те, которые непременно хотели бы показать на выставке; потом, на свое усмотрение (кураторское), я оставцяла из них немногие кучшие - те, что отличались своей завершенностью, содержательной и формальной: значительностью тем, выразительностью образов, оригинальностью манеры, мастерством исполнения. Бескомпромиссность отбора, нацеленного на «большой стиль», отсеяла вал низкопробной продукции: робких этюдов, откровенных цитат, гламурных картинок, сувенирных поделок... Остались избранные, причем не всегда равноценные межАу собой (природа и степень таланта их авторов часто бывали

10 Первоначально, желая открыть для себя новые имена, я разослала «положение о выставке» в сибирские коллективы ВТОО «Союз художников России» еще в феврале 2015 г. Однако попытка не очень-то удалась - долгое молчание было ответом. Лишь первого июня конечный срок подачи заявок - хлынул поток, в основном от начинающих авторов, очень молодых. Понятно, что предлагаемые ими работы еще очень робкие, порой неумелые, не шли ни в какое сравнение с теми, которые придирчиво и неспешно выбирала в течение полугода, связываясь с художницами - с каждой персонально. 
несопоставимы), но вполне отвечающие предъявленным требованиям, общему уровню, статусу выставки.

Предпочтение отдавалось произведениям, созданным за последнюю четверть века, преимущественно после милмениума, начиная с 2000-х. Чтобы развернуть панораму именно современного творчества региональных художниц - во всем многообразии видов и жанров, индивидуальных исканий и стилевых направлений. Чтобы потом на этой основе выявить тенденции и особенности развития их искусства, яркие таланты и новые имена, чтобы оценить их профессиональный уровень и творческий потенциал. САовом, чтобы осмыслить женскую долю в искусстве Сибири.

Всего на выставке показано около Авухсот работ, и только четыре из них Аатированы концом прошлого века. Это графический триптих (1983) Т.М. Бельчиковой (Томск) и «Ровесница века. Портрет Марии Тихоновны Юмановой» (1995) Е.Н. Юмановой (Кемерово). Исключение слелано потому, что Аанные работы, не теряя со временем своей актуальности, весьма значительны в искусстве художниц, причем настолько, что отказаться от них значило бы обеднить представление о творчестве уважаемых авторов и, больше того, - об искусстве Сибири в целом.

Поскольку проект кураторский, то окончательное решение в выборе и участниц и их экспонатов оставацось за мной как инициатором и организатором выставки ${ }^{11}$. Мне же в этом помогал исключительно опыт - сумма интуиций, сложившаяся за три с половиной Аесятилетия, что работаю в сфере художественной культуры. Чувство Аичной ответственности и профессиональная честь заставляли быть предельно требовательной, принципиальной и по возможности объективной, что Аостаточно трудно, поскольку индивидуальны и сама природа искусства, и его восприятие, которое, как известно, у каждого свое.

ОАнако субъективность подхода - как основа Аюбого кураторского проекта - всегда оправдана: только так, обретая цельность и целостность, выставка внятно отражает замысел автора, в Аанном случае - парадоксальность концепции, органично соединившей Ава противоположных начала: специфическое и универсальное. Притом что проект «Песнь Песней» представляет творчество искцючительно сибирских художниц, нельзя не заметить, что он демонстрирует не какое-то особенное женское искусство нашего края, а искусство. Таким образом, утверждая равноправие полов, проект воплощает задуманное: переводит «женский вопрос» из социального в художественный.

Осуществить столь масштабный выставочный проект стало возможным благодаря финансовой помощи Министерства культуры Российской Федерации (Федеральная целевая программа «Культура России»), подлержавшего инициативу Кемеровского областного музея изобразительных искусств (КОМИИ), причем не в первый раз.

Претендуя быть центром по изучению, комплектованию и популяризации современного искусства Сибири, наш музей уже провел такие межрегиональные выставки, как «Прямая речь» (2011), «Аз Есмь» (2013), «Большой стиль» (2014). КажАая из них имела свои задачи, весьма конкретные (например, выставка «Прямая речь» представляла исключительно жанр автопортрета). ОАнако все они преследовали общие

\footnotetext{
${ }^{11}$ Макс Фрай (творческий псевдоним художницы и писательницы Светланы Мартынчик): «По большому счету, кураторская деятельность - это такая принципиально иная форма авторства в искусстве» [4].
} 
цели: консолидация творческих сил Сибирского федерального округа, исследование и актуализация его современных художественных процессов, продвижение Кузбасса как полноправного участника культурной жизни обширного края, а КОМИИ - как открытого музея, престижной выставочной площадки со своими приоритетами и

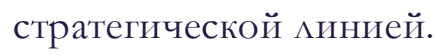

Практическим результатом «Песни Песней» станет колмекция произведений, которые, по окончании выставки, останутся в собрании КОМИИ, существенно пополнив «сибирский» раздел, магистральный в комплектовании - на протяжении вот уже четырех с половиной десятилетий. Таков был итог и всех предыдущих проектов, благодаря которым наши фонды увеличились на 79 еАиниц хранения, Ааров и приобретений ${ }^{12}$. Причем всякий раз это произведения по-настоящему избранные, прошедшие тройной уровень оценочной экспертизы: после авторского и кураторского отборов, тщательных и пристрастных, они выделены из экспозиций - как мучшие из кучших.

Честно признаться, музейные интересы во многом обусловили единый формат этих моих проектов, реализующихся на территории КОМИИ: отвечая специфике нашего комплектования, все они, как один, представАяют современное искусство Сибири в актуальных аспектах, высокими образцами (по принципу: «лучше меньше, да Аучше»). Такая мотивация, кажущаяся на первый взгляд местечковой, мокальной, по сути исполнена глубинного смысла и будущности: профессиональное исследование (проект) получает свою завершенность, «сибирская» колмекция в музейном собрании интенсивность развития, а история - «сибирскую» колцекцию.

\section{Аитература}

1. Альчук А. Женский взгляд на «искусство женского рода» [Электронный ресурс]. URL: http://www.owl.ru/content/art/p27016.shtml (Аата обращения 26.07.2015).

2. Женское искусство как проект будущего [Электронный ресурс]. URL: http://www.svoboda.org/content/article/1615853.html (Аата обращения 26.07.2015).

3. Муратов П.А. Художественная жизнь Сибири 20-х годов. - А.: Художник РСФСР, 1974. - 143 c.
4. Фрай
M.
Куратор
[Электронный
pecypc].
URL: http://azbuka.gif.ru/alfabet/k/curator/ (Аата обращения 02.08.2015). 12 По завершении выставочного проекта «Прямая речь» в фонды кОмИИ поступило 43
экспоната. 


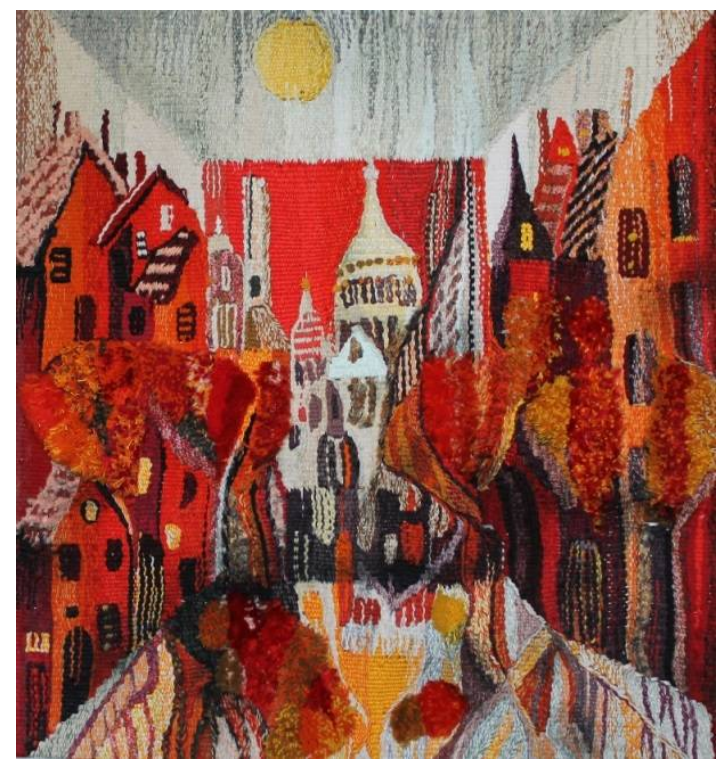

Акимова И. (Кемерово). Осень в Париже. 2010. Шерсть, ручное ткачество. $120 \times 100$.

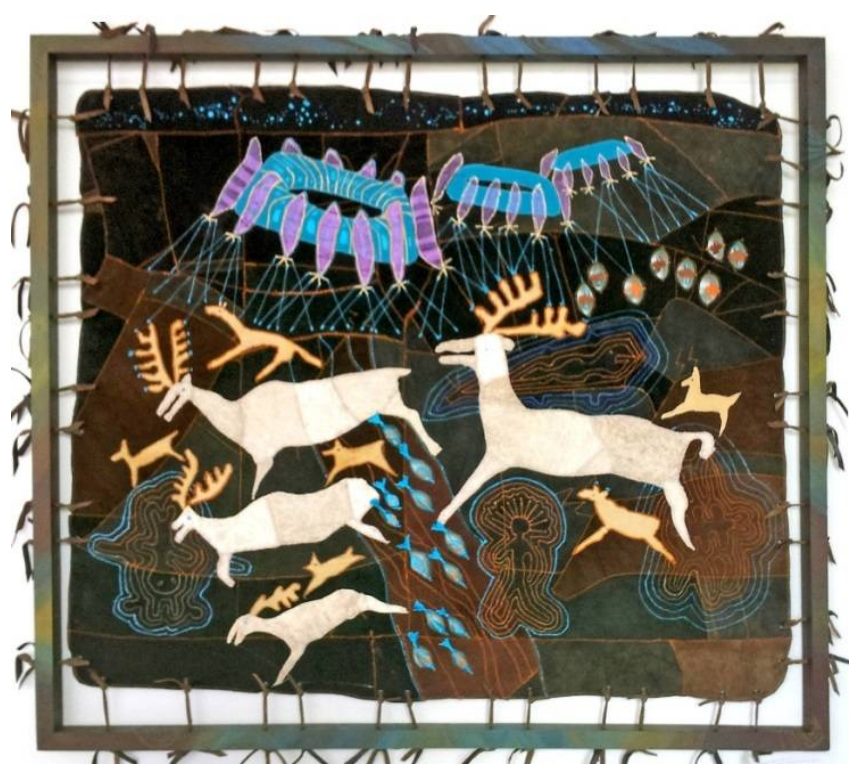

Архиповская А. (Новокузнечк). Контакт. 2013. Кожа, шелк, аппликачия. $80 \times 90$.

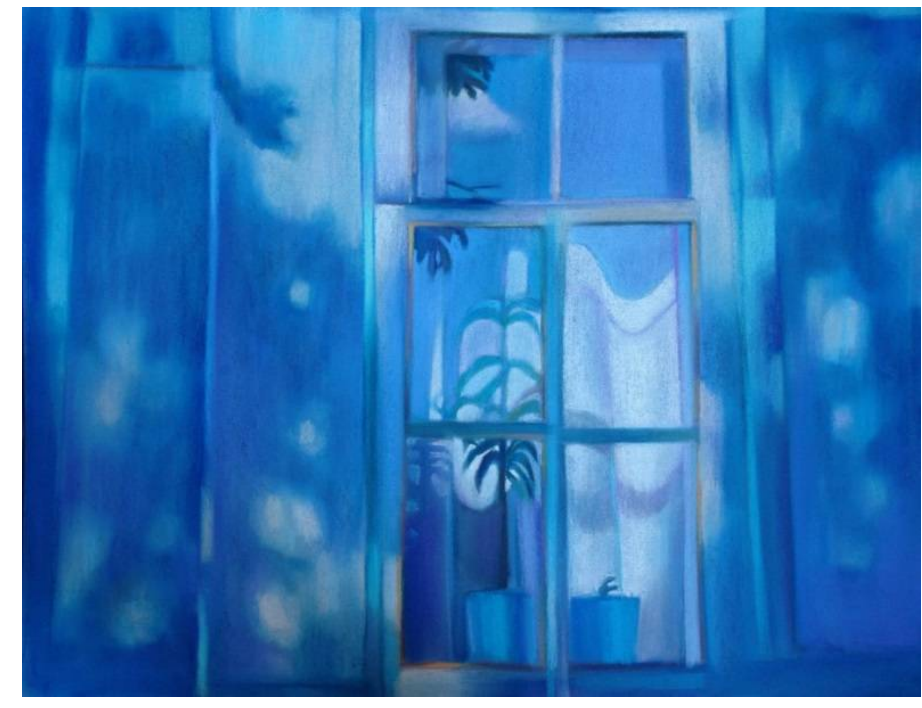

Белозерова А. (Омск). Столетник. 2011. Бумага тонированная, пастель. $50 \times 65$.

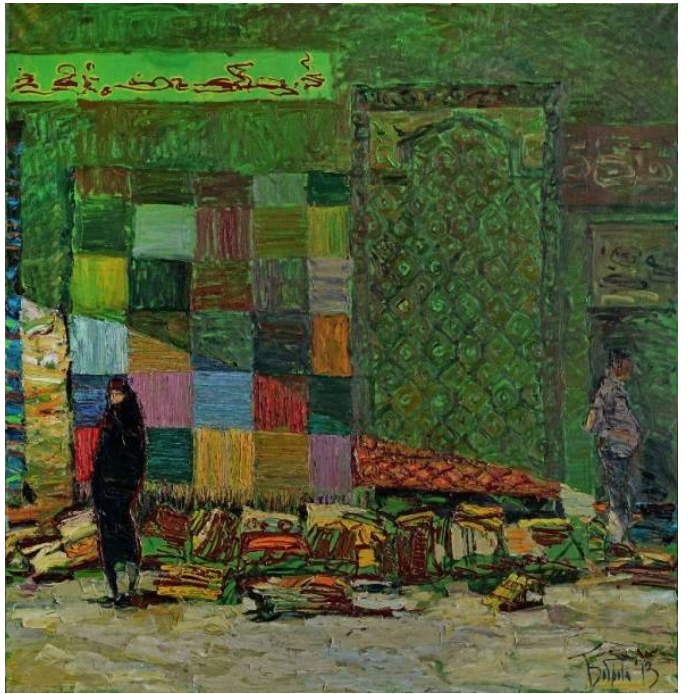

Боброва Е. (Омск). Инъ-ян. 2013.

Холст, масло. $160 \times 155$. 


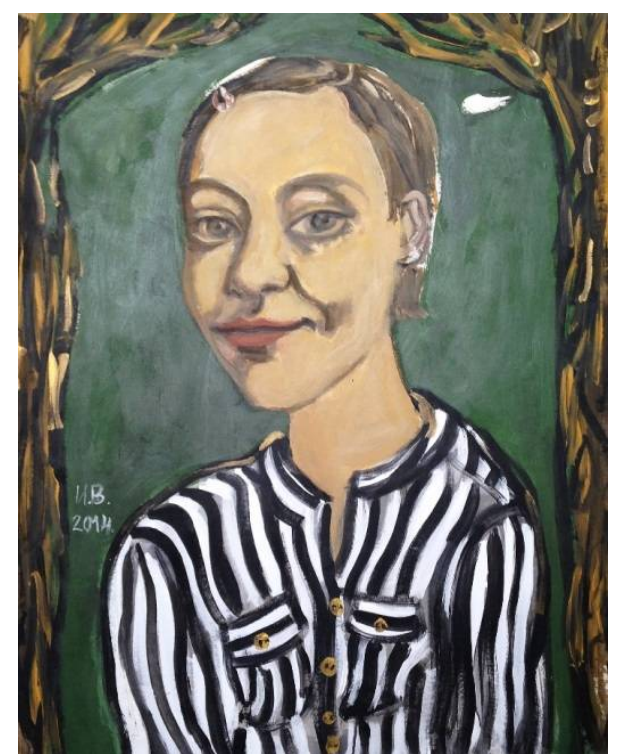

Верпета И. (Красноярск). Красивая я сегодня. 2014. Флизелин, акрил, лак. $105 \times 84$.

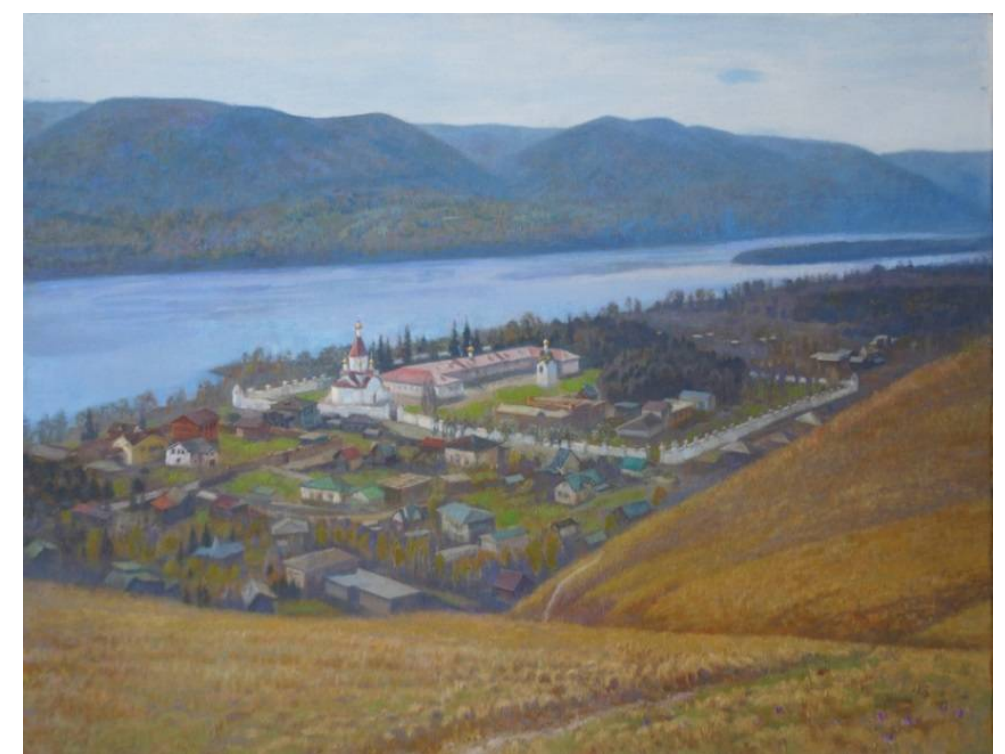

Войнова-Чибис 1. (Красноярск). Монаствгрь Успения Богородищь на Енисее. 2015. Холст, масло. $100 \times 130$.

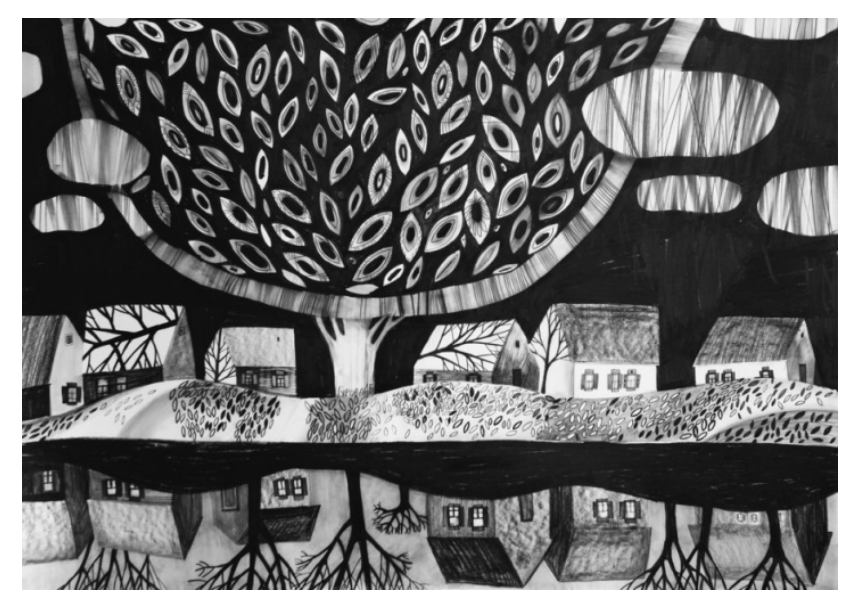

Гурова А. (Омск). Auсmопад. Аерево. 2013. Бумага, карандаш. $70 \times 100$.

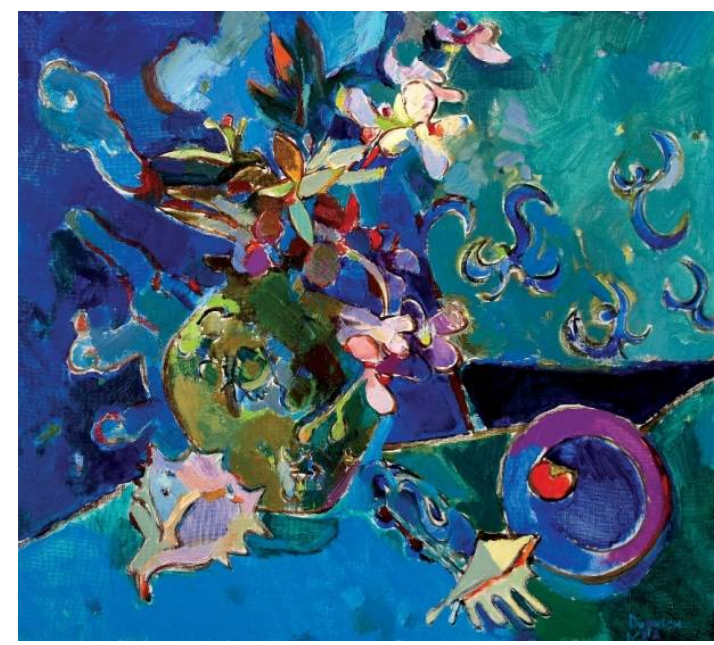

Аовнич Н. (Иркутск). Морской натюрморт. 2014. Холст, масло. $90 x$ 100.

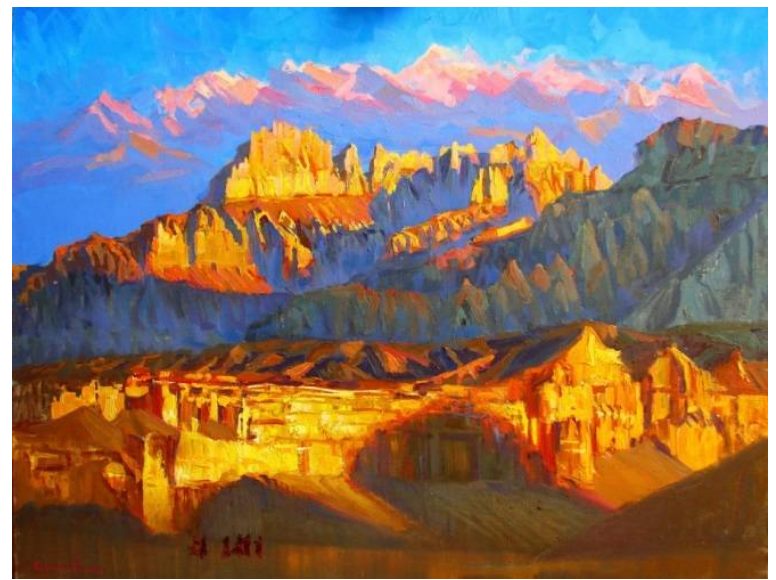

Аемкина Е. (Барнаул). Золотье дворивг Тибета. 2011. Холст, масло. $95 \times 120$.

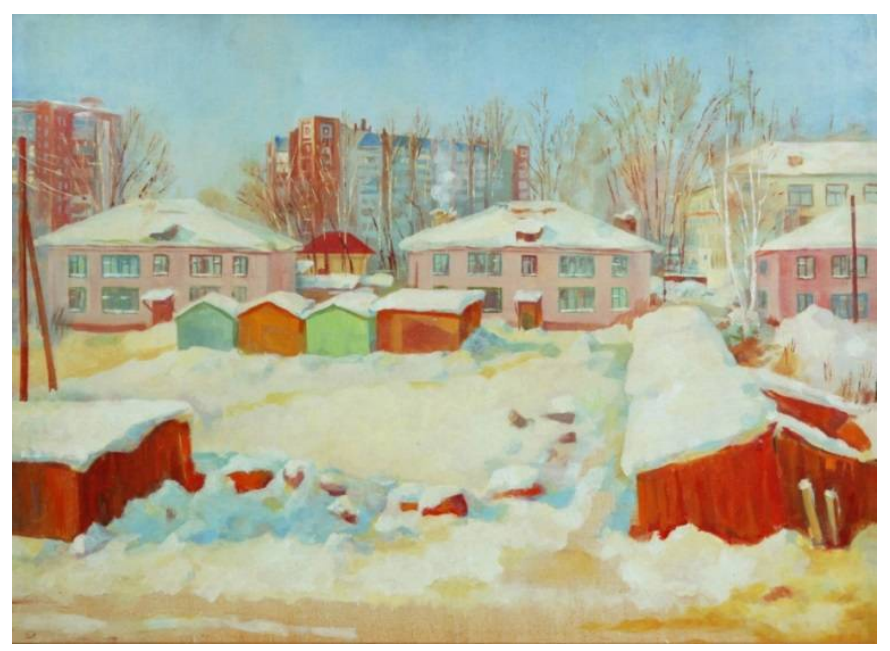

Завьялова Т. (Томск). Морозныий денъ. 2012. Холст, масло. $80 \times 110$. 


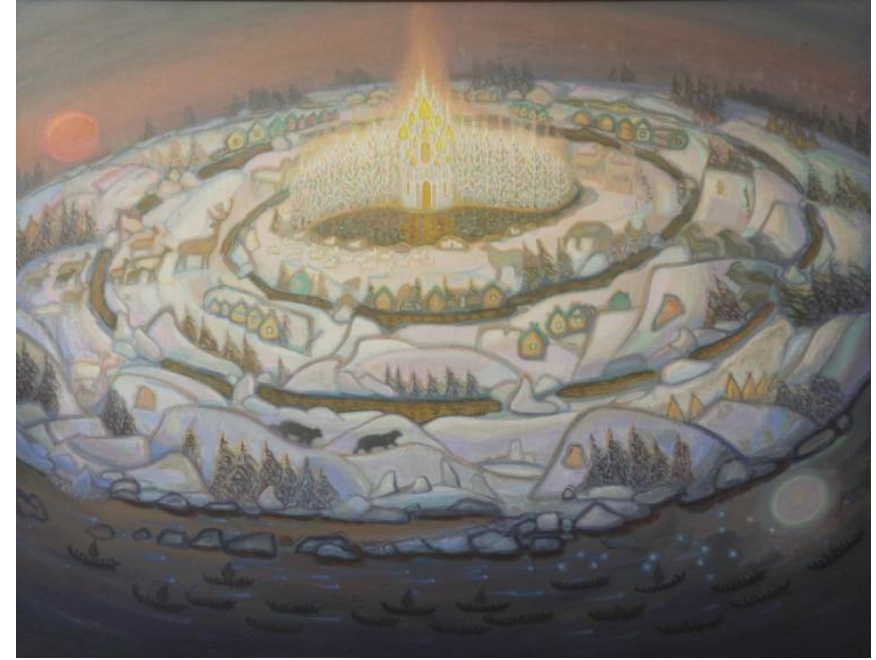

Иванова А. (Красноярск). Источник. 1999. Холст, мacro. $110 \times 85$.

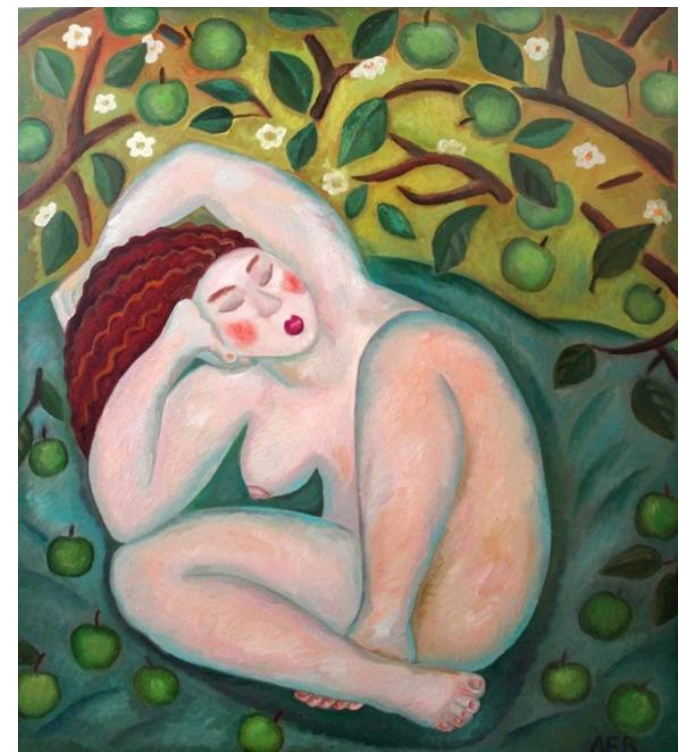

Аихачкая Е. (Красноярск). Аетняя ночь. 2015. Холст, мacлo. $111 \times 96$.

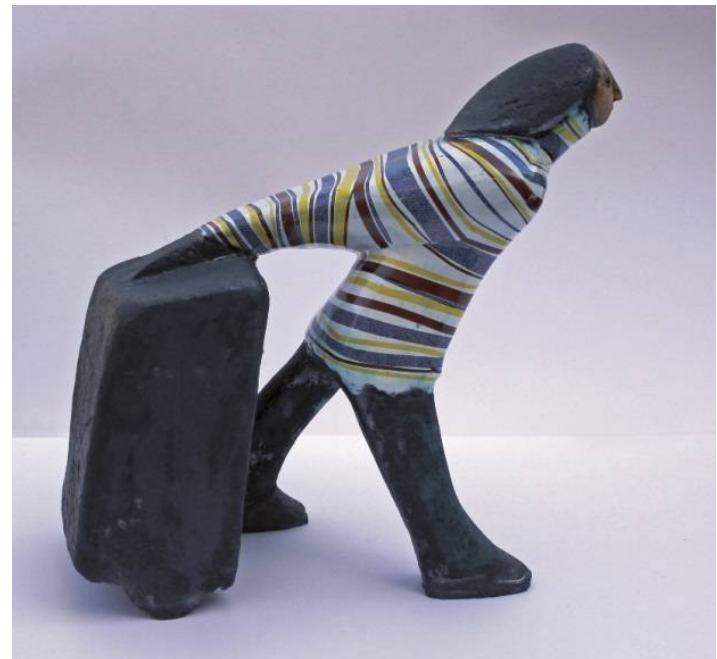

Краснова Е. (Красноярск). Аюои и вещи. 2014. Шамот, флюсныг ангобъ, оксидъг, надглазурная росписъ. 31,5 × $14 \times 27$.

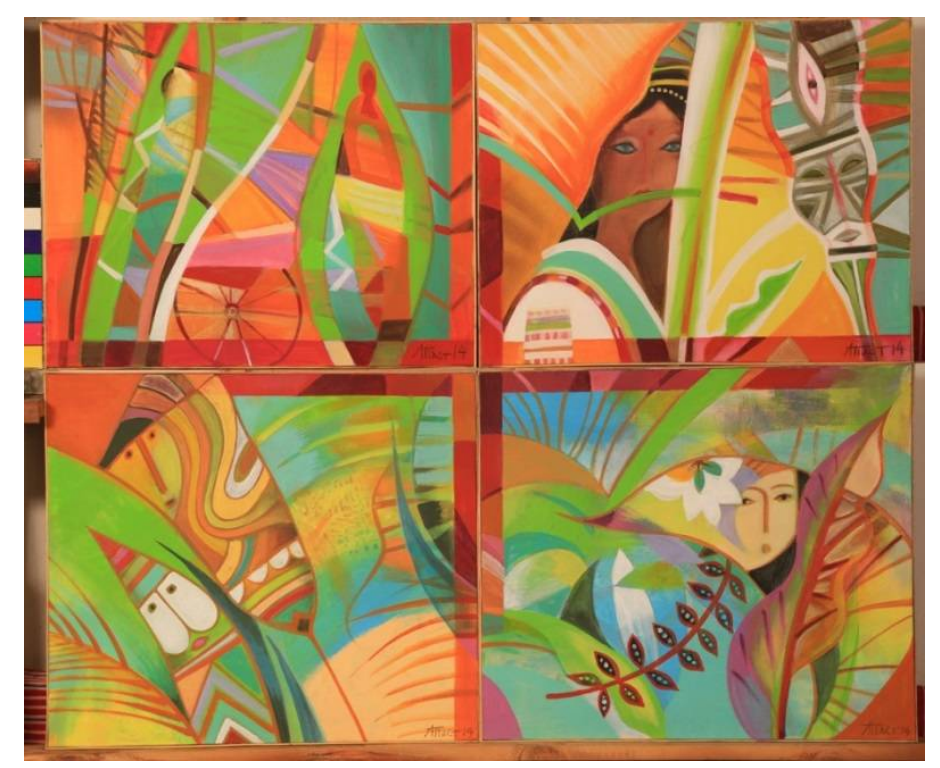

Пастушкова А. (Барнаул). Живопись на пальмовыхх листьях. Полиптих. 2014. Холст, акрил. $60 \times 70$ (2 um.), $50 \times 60$ (2 um.). 


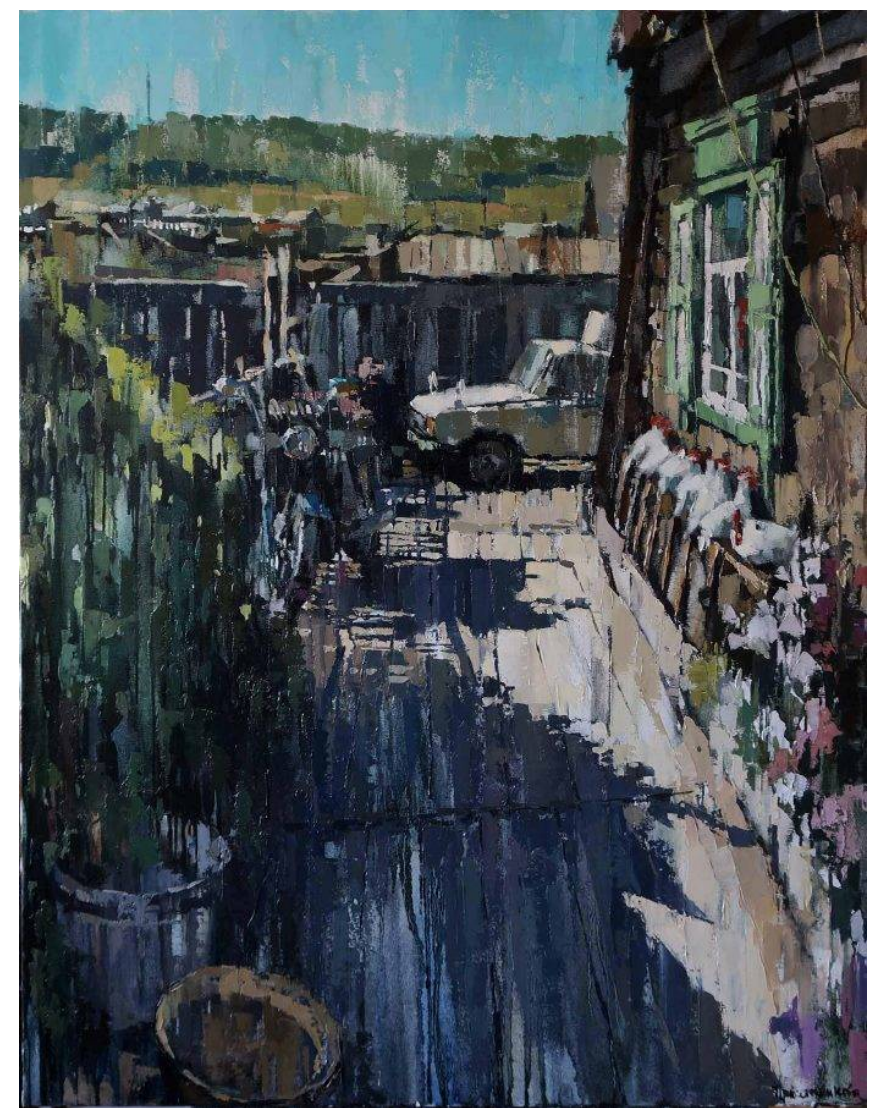

Присянсникова Р. (Иркутск). На солныике. 2015. Холст, масло. $110 \times 85$.

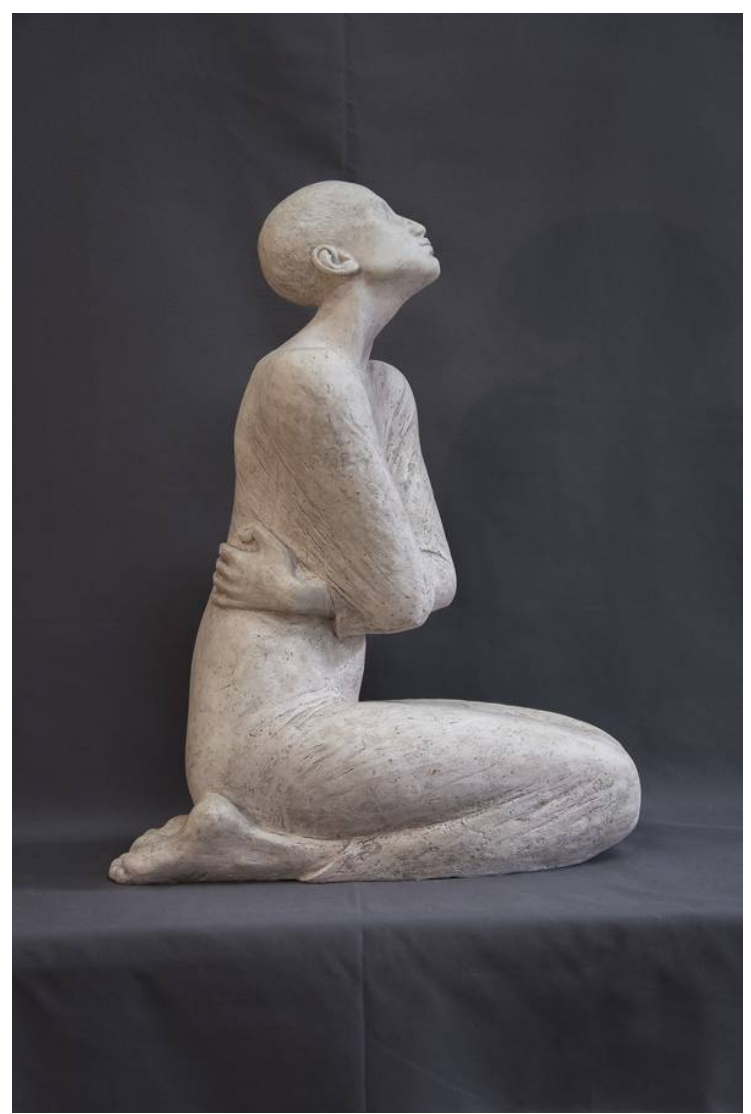

Скрипкина Н. (Омск). Сныг о Египте. 2009. Гипс тонированный. $55 \times 45 \times 30$.

Статья поступила в редакцию 10.08.2015 г. 
DOI 10.25712/ASTU.2518-7767.2015.01.010

\title{
SONG OF SONGS
}

Chertogova Marina Yuryevna

Art critic, deputy director on the scientific work

of the Kemerovo Museum of Fine Arts,

Member of the Union of Artists of Russia, member of the Association of Art Critics

of Russia (AIS).

Russia, Kemerovo.

chertog_marina@mail.ru

\begin{abstract}
The article presents the history and overview of the Song of Songs exhibition project in the Kemerovo Regional Museum of Fine Arts. The exhibition featured the work of women artists of the Siberian Federal District. Parallels are being drawn with the exhibition «Feminine Art», held in 2002 at the State Tretyakov Gallery.

Keywords: exhibition, Song of Songs, women artists, Siberia, Kemerovo.

\section{Bibliographic description for citation:}

Chertogova M.Yu. Song of Songs. Iskusstvo Evrazii - The Art of Eurasia, 2015, No. 1 (1), pp. 123-134. DOI: 10.25712/ASTU.2518-7767.2015.01.010. Available at: https:// readymag.com/u50070366/416035/24/ (In Russian).
\end{abstract}

\section{References}

1. Alchuk A. Zhenskiy vaglyad na «iskusstvo zhenskogo roda» [Female look at the «feminine art»]. Available at: http://www.owl.ru/content/art/p27016.shtml (accessed 26.07.2015). (In Russian).

2. Zhenskoye iskusstvo kak proyekt budushchego [Female art as a project of the future]. Available at: http://www.svoboda.org/content/article/1615853.html (accessed 26.07.2015). (In Russian).

3. Muratov P.D. Khudozhestvennaya zhizn' Sibiri 20-kh godov [Art life of Siberia of the 20s]. Leningrad, Khudozhnik RSFSR, 1974. 143 p.

4. Fray M. Kurator [Curator]. Available at: http://azbuka.gif.ru/alfabet/k/curator/ (accessed 02.08.2015). (In Russian).

Received: August 10, 2015. 